DWORKIN, Ronald. Justiça para ouriços. Tradução de Pedro Elói Duarte. Coimbra: Almedina, 2012.

\title{
Justiça para ouriços
}

\section{Justice OF HedgeHOGS}

* Tiago Brene

Justice for Hedgehogs - Justiça para Ouriços - é o último livro publicado em vida por Ronald Dworkin, lançado originalmente no ano de 2011. Na época de seu lançamento Dworkin chegou a disponibilizar uma página na internet cujo endereço reportava o nome da obra em inglês. A intenção de Dworkin era capitar as críticas dirigidas ao seu trabalho e disponibilizar eventuais respostas aos críticos na própria página na rede mundial de computadores.

A partir de uma frase do poeta grego, Arquíloco, que teria se tornado célebre por Isaiah Berlin, Dworkin esboça a estrutura da presente obra: " $a$ raposa sabe muitas coisas, mas o ouriço sabe uma coisa muito importante. O valor é uma coisa muito importante”. Valor, neste contexto, diz respeito ao modo de viver, em especial um modo de viver bem a partir da racionalização daquilo que se deve ou não fazer. A tese que permeia os diversos pontos tratados por Dworkin, é de que os valores são interdependentes, mas existe unidade de valor ao menos nas questões ética e moral.

Dworkin defende uma compreensão sobre os valores diferentes da maioria dos autores anglo-saxões. Dworkin sustenta a existência de verdades objetivas sobre o valor. Trata-se de uma compreensão diretamente oposto da ideia de que os valores expressam compromissos ou preferências. Isso porque, para Dworkin essas preferências, concessões ou mesmos compromissos, tem em foco apenas a vida privada e negligenciam a vida política. A distinção, no campo político, por exemplo, está em que tanto o governante quanto o cidadão participativo em uma democracia, não pode optar por uma teoria de justiça com base naquilo que lhe agrada, mas sim, com base naquilo que acredita que é realmente verdadeiro.

\footnotetext{
* Discente de pós-graduação Stricto Sensu do programa de Mestrado em Direito Negocial pela Universidade Estadual de Londrina -UEL, Bolsista CAPES. Especialista lato sensu em Direito do Estado, igualmente pela UEL. Ao som de "Índios", Álbum Legião Urbana II (1986), Legião Urbana. E-mail: tiagobrene@yahoo.com.br
} 
A independência do valor exige que ele não seja uma construção, a independência do valor desempenha papel importante na condução da tese do livro: os vários conceitos e departamentos do valor estão interligados mutualmente. Em síntese, Dworkin sustenta a independência metafísica dos valores. Independência metafísica significa que os valores não precisam reconciliar-se entre perspectiva teórica e prática, ou ainda, reconciliar entre fatos físicos ou fáticos com quimeras ou verdades psíquicas: uma ação absolutamente errada é errada ainda que ninguém a entenda como sendo algo errado.

Com Dworkin tem de lidar com algumas perguntas e objeções de ordem filosóficas que são fundamentais para defender em manter a tese de que os valores são independentes, por exemplo, de onde vem então os valores, e ainda, se não pluralismo de valores tal como tomada de concessões e escolha, como se justifica e explica os eventuais conflitos de valores?

Repare-se, que na ótica de Dworkin, tais conflitos podem ser intuídos tanto abstratamente quanto pragmaticamente em exemplos concretos. Devemos lembrar que Dworkin está insinuando a existência de uma unidade dos valores na medida que os valores devem ser verdadeiros, e como verdadeiros, não podem excluir-se por critérios de preferências. Sem confundir com o plano da linguagem, Dworkin dirá que os juízos de valor são verdadeiros não em razão de eventual correspondência fática ou mesmo ausência de conflitos, mas sim, em virtude de que, argumentativamente, possa ser realizada a defesa substantiva de determinado juízo de valor. Dessa forma, o domínio moral é argumentativo e não metafísico ou mesmo abstrato e bruto, razão pela qual eventuais conflitos podem, sim, existir. Contudo, a existência de conflito, segundo Dworkin, não indica a falta de unidade, pelo ao contrário, indica que tais valores estão unidos por unidade de valor maior e fundamental, a qual, produz resultados substantivos.

Estes juízos, embora tenham que ser verdadeiros tanto para ética quanto para a moral possuem conteúdos distintos. O juízo ético diria respeito aquilo que as pessoas deveriam fazer pra viver bem, ao passo que o juízo moral diria respeito aquilo que as pessoas deveriam fazer para tratar e conviver com as outras pessoas. Estes juízos, na visão de Dworkin não podem ser trabalhados apenas como excludentes. Ao contrário, mais liberdade, segundo essa visão, não deve importar em menos igualdade e vice-versa. Mais preocupação com a igualdade, por exemplo, não deve limitar a liberdade de alguns poucos, mas sim, expandir a liberdade de todos. 
Merece destaque, por fim, que nesta visão de Dworkin, dois grandes ensaios sobre a liberdade The liberty of the Ancients and the Liberty of the moderns, de Benjamin Constant, e Two Concepts of Liberty, de Isaiah Berlin, podem conduzir a um equívoco fundamental: a ideia de que as concepções liberdade negativa e positiva se excluem conforme o critério de pluralismo de valores. Aqui, dentre vários pontos altos do livro, Dworkin chama a atenção para a distinção das palavras em inglês Liberty - liberdade e Freedom autonomia -. A autonomia é uma zona de cada pessoa livre de ameaças ou interferências de outras pessoas ou comunidade política. Dworkin está convencido de que Berlin vê a autonomia - Freedom - e a liberdade - liberty - como sendo coextensivas. Para Dworkin, o constrangimento coercitivo de uma comunidade política, por exemplo, não necessariamente usurpa a autonomia de uma pessoa.

Resenha recebida em: 25/11/2014 Aprovado para publicação em: 25/11/2014

Como citar: DWORKIN, Ronald. Justiça para ouriços. Tradução de Pedro Elói Duarte. Coimbra: Almedina, 2012. Resenha de: BRENE, Tiago. Scientia Iuris. Londrina, v.19 n.2, p.235-237, dez.2014. DOI: 10.5433/1980-511X.2014 v18n2p235. 